THURSDAY, JUNE 9, I892.

\section{A PROFESSORIAL UNIVERSITY OF} LONDON.

\section{THE recent history of the London University question} affords decisive proof that the new University, which is to be the outcome of the labours of the Royal Commission now sitting, must be much more than a merely exclusive or merely local institution. Of the two main objects of a University in any English sense of the expression-the promotion of the higher education, and the advancement of learning - both must be equally subserved ; and neither will be attained if the new University be established on other than the broadest possible basis, or if its development be controlled and hindered by rivalries that could not but become of an ignoble character. In the course of discussion it has been made abundantly clear that a duplication of Universities in London would be a misfortune of the first magnitude, dividing resources and diverting energies into channels that would lead to many undesirable results. It is equally clear that a University, consisting of a federation of local educational institutions existing within the same narrow area, would be wanting both in unity and force : its government would tend to become a succession of compromises effected between the interests, almost wholly of a financial nature, of its constituent Colleges. It may, then, be taken as a conclusion accepted by the great majority of those who have given special attention to the subject that there should be one University, and one only, in London, and that it should not be of a federal character. To this position it is a simple corollary that the government of the proposed University should be vested mainly in a professorial body. Much the most important work of the University would be the enactment of curricula and syllabuses and the control of teaching and examination -work that can only be efficiently performed by those specially familiar with the subjects taught. With the Professors a proper number of Crown nominees should be associated to act as moderators and as representatives of general educational policy, as well as to guard the interests and assure the continued confidence of the public. With the mode of creation and with the functions of the usual Faculties, and with the details of examinational systems, we need not at present concern ourselves. In fact, the less the new University is fettered by any Charter or Act the better, and it would be a misfortune were the precedent followed of the complicated and minutely detailed Charter recently rejected by the Convocation of the London University. On that occasion, it must be admitted, Convocation made good use of its veto, but its continued possession of such a power would, we think, be a source of disquiet and danger, without any corresponding advantage to Convocation itself, or the University-especially a professorial University-or indeed to the public. A much more useful provision would be the grant of a power of appeal to some such Committee of the Privy Council as that by whose aid the Scotch Universities are enabled to settle their differences.

No. I I 80, voL. 46]
The possibility of any such University as we have indicated above ever coming into existence-and for a University of any other kind it is scarcely worth while to exert oneself-depends largely on the good will of the existing Colleges. They must follow the capital example set by Bedford College, and signify their willingness to be merged in and become part of a true London University with such reservations in respect of particular portions of their collegiate work as may be necessary. As far as the professorial staffs of these Colleges are concerned, there can be little doubt but that they would hail such an event; but it is possible that the governing bodies may take a different view. And with regard to the Medical Schools, the reservations touching their purely professional work, must, from the nature of the case, be extensive.

Though, for the moment, the question of a new University is chiefly interesting from the point of view of science and medicine, what for the sake of brevity may be termed the arts aspect of the question must not be neglected. There are very few science students who do not followand follow of necessity-special courses of instruction in fairly equipped laboratories; but the arts student is less constrained in his mode and course of study - he has, indeed, in London less opportunity of benefiting by adequate instruction in the subjects of his studies. The stimulus to every form of education that the new University may be expected to give will supply this deficiency; but meanwhile, and probably to a greater or less extent always, the case of the "private student" in arts will have to be considered. We shall not enter upon it here. Our object in mentioning the case of the arts student is rather to show that the interests of the two great divisions of human knowledge are at one in the matter of the proposed University. It may be added that the "private student" difficulty, so far as it exists, should be left to be dealt with by the new University. It is limited in character, though extensive in scope, and is very far indeed from being insurmountable.

To resume. We are entirely in favour of a single non-exclusive London University, mainly, or at least adequately, of a professorial character-which by no means necessarily involves the extreme teacher-examiner system-controlling both teaching and examination, and being or becoming, by absorption or otherwise, homogeneous in interest, and in the highest degree authoritative in function. All these features are entirely novel; they are not, we believe, possessed by any British University. And herein lies the practical difficulty now to be confronted. The present opportunity for creating such a University is not likely to recur, at all events for some generations to come. What is to be done to make the best of it? The Royal Commission is fully aware of the greatness of the task committed to it, and has entered upon its labours in no niggard, narrow, or unappreciative spirit. But the Commission must be aided by educational opinion clearly thought out and firmly expressed. It must have the support of the London University, of the great Colleges, of the Medical Schools, and of the professorial body in London, who should be aided by the sympathy of their brethren in the provinces-a sympathy, there is good 
reason to believe, that will not be wanting. Such professorial opinion will include that of the staffs of the Colleges and Schools, and of those members at least of the Senate and Convocation of the University of London who are or have been engaged in professorial work. So powerful a body of opinion cannot but exert a great indeed, a decisive-influence upon what may be termed the lay elements of the governing bodies, whom we can only reach through their professorial colleagues.

It is difficult to see how the arguments of eminent specialists in support of the general arguments called forth by the occasion can be rejected, when once the novelty of their proposals has been got over. Convocation, with an appeal to the Privy Council, will have a far more usable and useful power than is inherent in the bare obstructiveness or quasi-terrorism of the veto. The Senate in Burlington Gardens will scarcely refuse to complete the University character of the great institution it governs, and perfect its educational machinery, by placing the responsible direction of the higher education of all its students, without exception or distinction, in the hands of the most eminent representatives of those who have made such education the business of their lives. The Medical Schools will only give up the teaching they are least adapted to furnish, and in lieu of being scattered entities, will become integral portions of a great whole. The private arts student will retain every advantage and privilege he possesses, and cannot but gain by working under syllabuses prepared by past masters in the art of teaching.

Perhaps the best procedure to be adopted by the Professoriate, with whom the initiation of any active propaganda must lie, will be to lay their views before the governing bodies by deputation, and before the Commission by the individual testimony of such among them as may be invited to give evidence on the question. Here a word of caution may not be out of place. Details of a ministerial nature should be avoided as much as possible, for until the main lines of any scheme are settled, it is difficult to say what details are possible or necessary. It is still more important to shun any approach to doctrinairism, the besetting vice of professordom, and treat every principle as modifiable by the circumstances of history, national habit, and environment.

On the financial aspect of the question we can say little. The establishment of a new University will cost money, but no great sum will be needed to start with. The University will, of course, be independent, and the necessary expenses will be defrayed in part by an annual Government grant. Among other sources of income, the funds at the disposal of the County Council may perhaps be counted, and with a view to such assistance it might be found advisable that the University should have a commercial and technical, as well as a purely academical side.

But for the moment, what is of most importance is, we repeat, that the London Professoriate should organize itself, formulate its principles of action in the sense above indicated, and use its influence, publicly and privately, to procure their acceptance as far as circumstances may show to be possible.

$$
\text { No. I I } 80 \text {, voL. } 46]
$$

\section{INDIAN BOTANY.}

Annals of the Royal Botanic Garden, Calcutta. Vol. III. (I) The Species of Pedicularis of the Indian Empire and its Frontiers, by D. Prain, M.B., F.R.S.E., Curator of the Herbarium. (2) The Magnoliaceæ of British India, by G. King, M.B., LL.D., F.R.S., C.I.E., Superintendent of the Garden. (3) The Genus Gomphostemma, by D. Prain. (4) The Species of Myristica of British. India, by G. King. 4to, pp. 350, tt. 174. (Calcutta : Printed at the Bengal Secretariat Press, I891.)

THE two previous volumes of this publication are devoted entirely to the illustration and description of the arboreous element in the Indian Flora, and the letter-press is solely the work of Dr. King. Volume I. deals with the difficult genus Ficus, illustrated by 232 plates; and the second volume treats of the almost equally difficult genus Quercus and the allied Castanopsis, as well as the genus Artocarpus, of which seventeen species are described and figured. As may be seen from the list of papers given above, the work in the present volume is partly by Dr. King, and partly by his Curator, Dr. Prain ; the former continuing his valuable labours on the trees of India, whilst Dr. Prain has taken up two herbaceous genera. A critical review of this ponderous volume would require more space than could be given to it in the pages of NATURE, and a much deeper knowledge of the subjects than the writer possesses; but it is not a difficult task to give an idea of the nature and quality of the series of monographs it contains. At the outset one is disposed to find fault with the bulk and fourteen pounds weight of this book, because it is really fatiguing to handle, and smaller volumes are in every way more desirable. Fortunately, the present volume may be conveniently bound in three nearly equal parts, as each monograph has its separate title-page and index. Indeed, it might be preferable to bind each of the four monographs separately.

The present volume, it will be perceived, is partly devoted to utilitarian botany, which will be welcome to the forestry department, as well as to botanists generally, and partly to botany of a kind that appeals more especially to the biologist. Dr. Prain's elaborate and painstaking monograph of the genus Pedicularis belongs to the latter category, and may be recommended for study to the young aspirant for honours in the same direction as a model of thoroughnéss, so far as external morphology goes. To persons acquainted only with our two native species of Pedicularis, the wide range of modification exhibited in the forms of the corolla is surprising, and reminds one of Prof. Huxley's remark that the genus Gentiana, as generally cirrumscribed, presents nearly as much variation in the shape of the corolla as all the genera of the Gentianaceæ combined. This polymorphism is sufficiently illustrated in the comparatively recent monograph of the whole genus Pedicularis by the late Mr. Maximowicz. He figures the flowers of all the species known to him, whilst Dr. Prain figures the plants, or portions of the plants, of all the Indian species, as well as their flowers. Great as is the variety, however, in the size and shape of the corolla in Pedicularis, it would be wrong to 